\title{
Nutrient timing revisited: is there a post-exercise anabolic window?
}

\author{
Alan Albert Aragon ${ }^{1}$ and Brad Jon Schoenfeld ${ }^{2 *}$
}

\begin{abstract}
Nutrient timing is a popular nutritional strategy that involves the consumption of combinations of nutrients-primarily protein and carbohydrate-in and around an exercise session. Some have claimed that this approach can produce dramatic improvements in body composition. It has even been postulated that the timing of nutritional consumption may be more important than the absolute daily intake of nutrients. The post-exercise period is widely considered the most critical part of nutrient timing. Theoretically, consuming the proper ratio of nutrients during this time not only initiates the rebuilding of damaged muscle tissue and restoration of energy reserves, but it does so in a supercompensated fashion that enhances both body composition and exercise performance. Several researchers have made reference to an anabolic "window of opportunity" whereby a limited time exists after training to optimize training-related muscular adaptations. However, the importance - and even the existence - of a post-exercise 'window' can vary according to a number of factors. Not only is nutrient timing research open to question in terms of applicability, but recent evidence has directly challenged the classical view of the relevance of post-exercise nutritional intake with respect to anabolism. Therefore, the purpose of this paper will be twofold: 1) to review the existing literature on the effects of nutrient timing with respect to post-exercise muscular adaptations, and; 2) to draw relevant conclusions that allow practical, evidence-based nutritional recommendations to be made for maximizing the anabolic response to exercise.
\end{abstract}

\section{Introduction}

Over the past two decades, nutrient timing has been the subject of numerous research studies and reviews. The basis of nutrient timing involves the consumption of combinations of nutrients--primarily protein and carbohydrate--in and around an exercise session. The strategy is designed to maximize exercise-induced muscular adaptations and facilitate repair of damaged tissue [1]. Some have claimed that such timing strategies can produce dramatic improvements in body composition, particularly with respect to increases in fat-free mass [2]. It has even been postulated that the timing of nutritional consumption may be more important than the absolute daily intake of nutrients [3].

The post-exercise period is often considered the most critical part of nutrient timing. An intense resistance training workout results in the depletion of a significant proportion of stored fuels (including glycogen and amino acids) as

\footnotetext{
* Correspondence: brad@workout911.com

${ }^{2}$ Department of Health Science, Lehman College, Bronx, NY, USA

Full list of author information is available at the end of the article
}

well as causing damage to muscle fibers. Theoretically, consuming the proper ratio of nutrients during this time not only initiates the rebuilding of damaged tissue and restoration of energy reserves, but it does so in a supercompensated fashion that enhances both body composition and exercise performance. Several researchers have made reference to an "anabolic window of opportunity" whereby a limited time exists after training to optimize trainingrelated muscular adaptations [3-5].

However, the importance - and even the existence of a post-exercise 'window' can vary according to a number of factors. Not only is nutrient timing research open to question in terms of applicability, but recent evidence has directly challenged the classical view of the relevance of post-exercise nutritional intake on anabolism. Therefore, the purpose of this paper will be twofold: 1) to review the existing literature on the effects of nutrient timing with respect to post-exercise muscular adaptations, and; 2) to draw relevant conclusions that allow evidence-based nutritional recommendations to be made for maximizing the anabolic response to exercise.

\section{Biomed Central}

(c) 2013 Aragon and Schoenfeld; licensee BioMed Central Ltd. This is an Open Access article distributed under the terms of the Creative Commons Attribution License (http://creativecommons.org/licenses/by/2.0), which permits unrestricted use, distribution, and reproduction in any medium, provided the original work is properly cited. 


\section{Glycogen repletion}

A primary goal of traditional post-workout nutrient timing recommendations is to replenish glycogen stores. Glycogen is considered essential to optimal resistance training performance, with as much as $80 \%$ of ATP production during such training derived from glycolysis [6]. MacDougall et al. [7] demonstrated that a single set of elbow flexion at $80 \%$ of 1 repetition maximum (RM) performed to muscular failure caused a $12 \%$ reduction in mixed-muscle glycogen concentration, while three sets at this intensity resulted in a $24 \%$ decrease. Similarly, Robergs et al. [8] reported that 3 sets of 12 RM performed to muscular failure resulted in a $26.1 \%$ reduction of glycogen stores in the vastus lateralis while six sets at this intensity led to a $38 \%$ decrease, primarily resulting from glycogen depletion in type II fibers compared to type I fibers. It therefore stands to reason that typical high volume bodybuilding-style workouts involving multiple exercises and sets for the same muscle group would deplete the majority of local glycogen stores.

In addition, there is evidence that glycogen serves to mediate intracellular signaling. This appears to be due, at least in part, to its negative regulatory effects on AMP-activated protein kinase (AMPK). Muscle anabolism and catabolism are regulated by a complex cascade of signaling pathways. Several pathways that have been identified as particularly important to muscle anabolism include mammalian target of rapamycin (mTOR), mitogen-activated protein kinase (MAPK), and various calcium- $\left(\mathrm{Ca}^{2+}\right)$ dependent pathways. AMPK, on the other hand, is a cellular energy sensor that serves to enhance energy availability. As such, it blunts energy-consuming processes including the activation of mTORC1 mediated by insulin and mechanical tension, as well as heightening catabolic processes such as glycolysis, beta-oxidation, and protein degradation [9]. mTOR is considered a master network in the regulation of skeletal muscle growth $[10,11]$, and its inhibition has a decidedly negative effect on anabolic processes [12]. Glycogen has been shown to inhibit purified AMPK in cell-free assays [13], and low glycogen levels are associated with an enhanced AMPK activity in humans in vivo [14].

Creer et al. [15] demonstrated that changes in the phosphorylation of protein kinase B (Akt) are dependent on pre-exercise muscle glycogen content. After performing 3 sets of 10 repetitions of knee extensions with a load equating to $70 \%$ of 1 repetition maximum, early phase postexercise Akt phosphorylation was increased only in the glycogen-loaded muscle, with no effect seen in the glycogen-depleted contralateral muscle. Glycogen inhibition also has been shown to blunt S6K activation, impair translation, and reduce the amount of mRNA of genes responsible for regulating muscle hypertrophy $[16,17]$. In contrast to these findings, a recent study by Camera et al. [18] found that high-intensity resistance training with low muscle glycogen levels did not impair anabolic signaling or muscle protein synthesis (MPS) during the early $(4 \mathrm{~h})$ postexercise recovery period. The discrepancy between studies is not clear at this time.

Glycogen availability also has been shown to mediate muscle protein breakdown. Lemon and Mullin [19] found that nitrogen losses more than doubled following a bout of exercise in a glycogen-depleted versus glycogen-loaded state. Other researchers have displayed a similar inverse relationship between glycogen levels and proteolysis [20]. Considering the totality of evidence, maintaining a high intramuscular glycogen content at the onset of training appears beneficial to desired resistance training outcomes.

Studies show a supercompensation of glycogen stores when carbohydrate is consumed immediately post-exercise, and delaying consumption by just 2 hours attenuates the rate of muscle glycogen re-synthesis by as much as $50 \%$ [21]. Exercise enhances insulin-stimulated glucose uptake following a workout with a strong correlation noted between the amount of uptake and the magnitude of glycogen utilization [22]. This is in part due to an increase in the translocation of GLUT4 during glycogen depletion $[23,24]$ thereby facilitating entry of glucose into the cell. In addition, there is an exercise-induced increase in the activity of glycogen synthase-the principle enzyme involved in promoting glycogen storage [25]. The combination of these factors facilitates the rapid uptake of glucose following an exercise bout, allowing glycogen to be replenished at an accelerated rate.

There is evidence that adding protein to a post-workout carbohydrate meal can enhance glycogen re-synthesis. Berardi et al. [26] demonstrated that consuming a proteincarbohydrate supplement in the 2-hour period following a 60 -minute cycling bout resulted in significantly greater glycogen resynthesis compared to ingesting a calorieequated carbohydrate solution alone. Similarly, Ivy et al. [27] found that consumption of a combination of protein and carbohydrate after a $2+$ hour bout of cycling and sprinting increased muscle glycogen content significantly more than either a carbohydrate-only supplement of equal carbohydrate or caloric equivalency. The synergistic effects of protein-carbohydrate have been attributed to a more pronounced insulin response [28], although it should be noted that not all studies support these findings [29]. Jentjens et al. [30] found that given ample carbohydrate dosing $(1.2 \mathrm{~g} / \mathrm{kg} / \mathrm{hr})$, the addition of a protein and amino acid mixture $(0.4 \mathrm{~g} / \mathrm{kg} / \mathrm{hr})$ did not increase glycogen synthesis during a 3-hour post-depletion recovery period.

Despite a sound theoretical basis, the practical significance of expeditiously repleting glycogen stores remains dubious. Without question, expediting glycogen resynthesis is important for a narrow subset of endurance sports where the duration between glycogen-depleting events is limited to less than approximately 8 hours [31]. Similar 
benefits could potentially be obtained by those who perform two-a-day split resistance training bouts (i.e. morning and evening) provided the same muscles will be worked during the respective sessions. However, for goals that are not specifically focused on the performance of multiple exercise bouts in the same day, the urgency of glycogen resynthesis is greatly diminished. High-intensity resistance training with moderate volume (6-9 sets per muscle group) has only been shown to reduce glycogen stores by 36-39\% [8,32]. Certain athletes are prone to performing significantly more volume than this (i.e., competitive bodybuilders), but increased volume typically accompanies decreased frequency. For example, training a muscle group with 16-20 sets in a single session is done roughly once per week, whereas routines with 8-10 sets are done twice per week. In scenarios of higher volume and frequency of resistance training, incomplete resynthesis of pre-training glycogen levels would not be a concern aside from the far-fetched scenario where exhaustive training bouts of the same muscles occur after recovery intervals shorter than 24 hours. However, even in the event of complete glycogen depletion, replenishment to pre-training levels occurs well-within this timeframe, regardless of a significantly delayed post-exercise carbohydrate intake. For example, Parkin et al [33] compared the immediate post-exercise ingestion of 5 high-glycemic carbohydrate meals with a 2-hour wait before beginning the recovery feedings. No significant between-group differences were seen in glycogen levels at 8 hours and 24 hours post-exercise. In further support of this point, Fox et al. [34] saw no significant reduction in glycogen content 24 hours after depletion despite adding $165 \mathrm{~g}$ fat collectively to the postexercise recovery meals and thus removing any potential advantage of high-glycemic conditions.

\section{Protein breakdown}

Another purported benefit of post-workout nutrient timing is an attenuation of muscle protein breakdown. This is primarily achieved by spiking insulin levels, as opposed to increasing amino acid availability [35,36]. Studies show that muscle protein breakdown is only slightly elevated immediately post-exercise and then rapidly rises thereafter [36]. In the fasted state, muscle protein breakdown is significantly heightened at 195 minutes following resistance exercise, resulting in a net negative protein balance [37]. These values are increased as much as $50 \%$ at the 3 hour mark, and elevated proteolysis can persist for up to 24 hours of the post-workout period [36].

Although insulin has known anabolic properties [38,39], its primary impact post-exercise is believed to be anti-catabolic [40-43]. The mechanisms by which insulin reduces proteolysis are not well understood at this time. It has been theorized that insulin-mediated phosphorylation of PI3K/Akt inhibits transcriptional activity of the proteolytic Forkhead family of transcription factors, resulting in their sequestration in the sarcoplasm away from their target genes [44]. Down-regulation of other aspects of the ubiquitin-proteasome pathway are also believed to play a role in the process [45]. Given that muscle hypertrophy represents the difference between myofibrillar protein synthesis and proteolysis, a decrease in protein breakdown would conceivably enhance accretion of contractile proteins and thus facilitate greater hypertrophy. Accordingly, it seems logical to conclude that consuming a protein-carbohydrate supplement following exercise would promote the greatest reduction in proteolysis since the combination of the two nutrients has been shown to elevate insulin levels to a greater extent than carbohydrate alone [28].

However, while the theoretical basis behind spiking insulin post-workout is inherently sound, it remains questionable as to whether benefits extend into practice. First and foremost, research has consistently shown that, in the presence of elevated plasma amino acids, the effect of insulin elevation on net muscle protein balance plateaus within a range of $15-30 \mathrm{mU} / \mathrm{L}$ [45,46]; roughly 3-4 times normal fasting levels. This insulinogenic effect is easily accomplished with typical mixed meals, considering that it takes approximately 1-2 hours for circulating substrate levels to peak, and 3-6 hours (or more) for a complete return to basal levels depending on the size of a meal. For example, Capaldo et al. [47] examined various metabolic effects during a 5-hour period after ingesting a solid meal comprised of $75 \mathrm{~g}$ carbohydrate $37 \mathrm{~g}$ protein, and $17 \mathrm{~g}$ fat. This meal was able to raise insulin 3 times above fasting levels within 30 minutes of consumption. At the 1-hour mark, insulin was 5 times greater than fasting. At the 5-hour mark, insulin was still double the fasting levels. In another example, Power et al. [48] showed that a $45 \mathrm{~g}$ dose of whey protein isolate takes approximately 50 minutes to cause blood amino acid levels to peak. Insulin concentrations peaked 40 minutes after ingestion, and remained at elevations seen to maximize net muscle protein balance $(15-30 \mathrm{mU} / \mathrm{L}$, or 104-208 pmol/L) for approximately 2 hours. The inclusion of carbohydrate to this protein dose would cause insulin levels to peak higher and stay elevated even longer. Therefore, the recommendation for lifters to spike insulin post-exercise is somewhat trivial. The classical post-exercise objective to quickly reverse catabolic processes to promote recovery and growth may only be applicable in the absence of a properly constructed preexercise meal.

Moreover, there is evidence that the effect of protein breakdown on muscle protein accretion may be overstated. Glynn et al. [49] found that the post-exercise 
anabolic response associated with combined protein and carbohydrate consumption was largely due to an elevation in muscle protein synthesis with only a minor influence from reduced muscle protein breakdown. These results were seen regardless of the extent of circulating insulin levels. Thus, it remains questionable as to what, if any, positive effects are realized with respect to muscle growth from spiking insulin after resistance training.

\section{Protein synthesis}

Perhaps the most touted benefit of post-workout nutrient timing is that it potentiates increases in MPS. Resistance training alone has been shown to promote a twofold increase in protein synthesis following exercise, which is counterbalanced by the accelerated rate of proteolysis [36]. It appears that the stimulatory effects of hyperaminoacidemia on muscle protein synthesis, especially from essential amino acids, are potentiated by previous exercise [35,50]. There is some evidence that carbohydrate has an additive effect on enhancing postexercise muscle protein synthesis when combined with amino acid ingestion [51], but others have failed to find such a benefit $[52,53]$.

Several studies have investigated whether an "anabolic window" exists in the immediate post-exercise period with respect to protein synthesis. For maximizing MPS, the evidence supports the superiority of post-exercise free amino acids and/or protein (in various permutations with or without carbohydrate) compared to solely carbohydrate or non-caloric placebo [50,51,54-59]. However, despite the common recommendation to consume protein as soon as possible post-exercise [60,61], evidencebased support for this practice is currently lacking. Levenhagen et al. [62] demonstrated a clear benefit to consuming nutrients as soon as possible after exercise as opposed to delaying consumption. Employing a withinsubject design,10 volunteers (5 men, 5 women) consumed an oral supplement containing $10 \mathrm{~g}$ protein, $8 \mathrm{~g}$ carbohydrate and $3 \mathrm{~g}$ fat either immediately following or three hours post-exercise. Protein synthesis of the legs and whole body was increased threefold when the supplement was ingested immediately after exercise, as compared to just $12 \%$ when consumption was delayed. A limitation of the study was that training involved moderate intensity, long duration aerobic exercise. Thus, the increased fractional synthetic rate was likely due to greater mitochondrial and/or sarcoplasmic protein fractions, as opposed to synthesis of contractile elements [36]. In contrast to the timing effects shown by Levenhagen et al. [62], previous work by Rasmussen et al. [56] showed no significant difference in leg net amino acid balance between $6 \mathrm{~g}$ essential amino acids (EAA) coingested with $35 \mathrm{~g}$ carbohydrate taken 1 hour versus 3 hours post-exercise. Compounding the unreliability of the post-exercise 'window' is the finding by Tipton et al. [63] that immediate pre-exercise ingestion of the same EAA-carbohydrate solution resulted in a significantly greater and more sustained MPS response compared to the immediate post-exercise ingestion, although the validity of these findings have been disputed based on flawed methodology [36]. Notably, Fujita et al [64] saw opposite results using a similar design, except the EAAcarbohydrate was ingested 1 hour prior to exercise compared to ingestion immediately pre-exercise in Tipton et al. [63]. Adding yet more incongruity to the evidence, Tipton et al. [65] found no significant difference in net MPS between the ingestion of $20 \mathrm{~g}$ whey immediately pre- versus the same solution consumed 1 hour postexercise. Collectively, the available data lack any consistent indication of an ideal post-exercise timing scheme for maximizing MPS.

It also should be noted that measures of MPS assessed following an acute bout of resistance exercise do not always occur in parallel with chronic upregulation of causative myogenic signals [66] and are not necessarily predictive of long-term hypertrophic responses to regimented resistance training [67]. Moreover, the postexercise rise in MPS in untrained subjects is not recapitulated in the trained state [68], further confounding practical relevance. Thus, the utility of acute studies is limited to providing clues and generating hypotheses regarding hypertrophic adaptations; any attempt to extrapolate findings from such data to changes in lean body mass is speculative, at best.

\section{Muscle hypertrophy}

A number of studies have directly investigated the longterm hypertrophic effects of post-exercise protein consumption. The results of these trials are curiously conflicting, seemingly because of varied study design and methodology. Moreover, a majority of studies employed both pre- and post-workout supplementation, making it impossible to tease out the impact of consuming nutrients after exercise. These confounding issues highlight the difficulty in attempting to draw relevant conclusions as to the validity of an "anabolic window." What follows is an overview of the current research on the topic. Only those studies that specifically evaluated immediate ( $\leq 1$ hour) post-workout nutrient provision are discussed (see Table 1 for a summary of data).

Esmarck et al. [69] provided the first experimental evidence that consuming protein immediately after training enhanced muscular growth compared to delayed protein intake. Thirteen untrained elderly male volunteers were matched in pairs based on body composition and daily protein intake and divided into two groups: P0 or P2. Subjects performed a progressive resistance training program of multiple sets for the upper and lower body. P0 
Table 1 Post-exercise nutrition and muscle hypertrophy

\begin{tabular}{|c|c|c|c|c|c|c|}
\hline Study & Subjects & Supplementation & $\begin{array}{l}\text { Protein matched } \\
\text { with Control? }\end{array}$ & $\begin{array}{l}\text { Measurement } \\
\text { instrument }\end{array}$ & Training protocol & Results \\
\hline $\begin{array}{l}\text { Esmarck } \\
\text { et al. [69] }\end{array}$ & $\begin{array}{l}13 \text { untrained } \\
\text { elderly males }\end{array}$ & $\begin{array}{l}10 \mathrm{~g} \text { milk/soy protein combo consumed } \\
\text { either immediately or } 2 \text { hours after exercise }\end{array}$ & Yes & $\begin{array}{l}\text { MRI and muscle } \\
\text { biopsy }\end{array}$ & $\begin{array}{l}\text { Progressive resistance training } \\
\text { consisting of multiple sets of lat } \\
\text { pulldown, leg press and knee } \\
\text { extension performed } 3 \text { days/wk } \\
\text { for } 12 \text { wk }\end{array}$ & $\begin{array}{l}\text { Significant increase in muscle CSA } \\
\text { with immediate vs. delayed } \\
\text { supplementation }\end{array}$ \\
\hline $\begin{array}{l}\text { Cribb and } \\
\text { Hayes [70] }\end{array}$ & $\begin{array}{l}23 \text { young } \\
\text { recreational male } \\
\text { bodybuilders }\end{array}$ & $\begin{array}{l}1 \mathrm{~g} / \mathrm{kg} \text { of a supplement containing } 40 \mathrm{~g} \\
\text { whey isolate, } 43 \mathrm{~g} \text { glucose, and } 7 \mathrm{~g} \text { creatine } \\
\text { monohydrate consumed either immediately } \\
\text { before and after exercise or in the early } \\
\text { morning and late evening }\end{array}$ & Yes & $\begin{array}{l}\text { DXA and muscle } \\
\text { biopsy }\end{array}$ & $\begin{array}{l}\text { Progressive resistance training } \\
\text { consisting of exercises for the } \\
\text { major muscle groups performed } \\
3 \text { days/wk for } 10 \text { wks }\end{array}$ & $\begin{array}{l}\text { Significant increases in lean body } \\
\text { mass and muscle CSA of type II } \\
\text { fibers in immediate vs. delayed } \\
\text { supplementation }\end{array}$ \\
\hline $\begin{array}{l}\text { Willoughby } \\
\text { et al. [71] }\end{array}$ & $\begin{array}{l}19 \text { untrained } \\
\text { young males }\end{array}$ & $\begin{array}{l}20 \mathrm{~g} \text { protein or } 20 \mathrm{~g} \text { dextrose consumed } \\
1 \text { hour before and after exercise }\end{array}$ & No & $\begin{array}{l}\text { Hydrostatic } \\
\text { weighing, muscle } \\
\text { biopsy, surface } \\
\text { measurements }\end{array}$ & $\begin{array}{l}\text { Progressive resistance training } \\
\text { consisting of } 3 \text { sets of } 6-8 \text { repetitions } \\
\text { for all the major muscles performed } \\
4 \text { days/wk for } 10 \text { wks }\end{array}$ & $\begin{array}{l}\text { Significant increase in total body } \\
\text { mass, fat-free mass, and thigh } \\
\text { mass with protein vs. carb } \\
\text { supplementation }\end{array}$ \\
\hline $\begin{array}{l}\text { Hulmi } \\
\text { et al. [72] }\end{array}$ & $\begin{array}{l}31 \text { untrained } \\
\text { young males }\end{array}$ & $\begin{array}{l}15 \mathrm{~g} \text { whey isolate or placebo consumed } \\
\text { immediately before and after exercise }\end{array}$ & No & $\begin{array}{l}\text { MRI, muscle } \\
\text { biopsy }\end{array}$ & $\begin{array}{l}\text { Progressive, periodized total body } \\
\text { resistance training consisting of } 2-5 \\
\text { sets of } 5-20 \text { repetitions performed } \\
2 \text { days/wk for } 21 \text { wks. }\end{array}$ & $\begin{array}{l}\text { Significant increase in CSA of the } \\
\text { vastus lateralis but not of the } \\
\text { other quadriceps muscles in } \\
\text { supplemented group versus } \\
\text { placebo. }\end{array}$ \\
\hline $\begin{array}{l}\text { Verdijk } \\
\text { et al. [73] }\end{array}$ & $\begin{array}{l}28 \text { untrained } \\
\text { elderly males }\end{array}$ & $\begin{array}{l}10 \mathrm{~g} \text { casein hydrolysate or placebo } \\
\text { consumed immediately before and after } \\
\text { exercise }\end{array}$ & No & $\begin{array}{l}\text { DXA, } C T \text {, and } \\
\text { muscle biopsy }\end{array}$ & $\begin{array}{l}\text { Progressive resistance training consisting } \\
\text { of multiple sets of leg press and knee } \\
\text { extension performed } 3 \text { days/wk for } \\
12 \text { wks }\end{array}$ & $\begin{array}{l}\text { No significant differences in } \\
\text { muscle CSA between groups }\end{array}$ \\
\hline $\begin{array}{l}\text { Hoffman } \\
\text { et al. [74] }\end{array}$ & $\begin{array}{l}33 \text { well-trained } \\
\text { young males }\end{array}$ & $\begin{array}{l}\text { Supplement containing } 42 \mathrm{~g} \text { protein (milk/ } \\
\text { collagen blend) and } 2 \mathrm{~g} \text { carbohydrate } \\
\text { consumed either immediately before and } \\
\text { after exercise or in the early morning and } \\
\text { late evening }\end{array}$ & Yes & DXA & $\begin{array}{l}\text { Progressive resistance training consisting } \\
\text { of } 3-4 \text { sets of } 6-10 \text { repetitions of multiple } \\
\text { exercises for the entire body peformed } 4 \\
\text { days/wk for } 10 \text { weeks. }\end{array}$ & $\begin{array}{l}\text { No significant differences in total } \\
\text { body mass or lean body mass } \\
\text { between groups. }\end{array}$ \\
\hline $\begin{array}{l}\text { Erskine } \\
\text { et al. [75] }\end{array}$ & $\begin{array}{l}33 \text { untrained } \\
\text { young males }\end{array}$ & $\begin{array}{l}20 \mathrm{~g} \text { high quality protein or placebo } \\
\text { consumed immediately before and after } \\
\text { exercise }\end{array}$ & No & MRI & $\begin{array}{l}4-6 \text { sets of elbow flexion performed } \\
3 \text { days/wk for } 12 \text { weeks }\end{array}$ & $\begin{array}{l}\text { No significant differences in } \\
\text { muscle CSA between groups }\end{array}$ \\
\hline
\end{tabular}


received an oral protein/carbohydrate supplement immediately post-exercise while P2 received the same supplement 2 hours following the exercise bout. Training was carried out 3 days a week for 12 weeks. At the end of the study period, cross-sectional area (CSA) of the quadriceps femoris and mean fiber area were significantly increased in the P0 group while no significant increase was seen in P2. These results support the presence of a post-exercise window and suggest that delaying post-workout nutrient intake may impede muscular gains.

In contrast to these findings, Verdijk et al. [73] failed to detect any increases in skeletal muscle mass from consuming a post-exercise protein supplement in a similar population of elderly men. Twenty-eight untrained subjects were randomly assigned to receive either a protein or placebo supplement consumed immediately before and immediately following the exercise session. Subjects performed multiple sets of leg press and knee extension 3 days per week, with the intensity of exercise progressively increased over the course of the 12 week training period. No significant differences in muscle strength or hypertrophy were noted between groups at the end of the study period indicating that post exercise nutrient timing strategies do not enhance training-related adaptation. It should be noted that, as opposed to the study by Esmark et al. [69] this study only investigated adaptive responses of supplementation on the thigh musculature; it therefore is not clear based on these results whether the upper body might respond differently to post-exercise supplementation than the lower body.

In an elegant single-blinded design, Cribb and Hayes [70] found a significant benefit to post-exercise protein consumption in 23 recreational male bodybuilders. Subjects were randomly divided into either a PRE-POST group that consumed a supplement containing protein, carbohydrate and creatine immediately before and after training or a MOR-EVE group that consumed the same supplement in the morning and evening at least 5 hours outside the workout. Both groups performed regimented resistance training that progressively increased intensity from $70 \% 1 \mathrm{RM}$ to $95 \% 1 \mathrm{RM}$ over the course of 10 weeks. Results showed that the PRE-POST group achieved a significantly greater increase in lean body mass and increased type II fiber area compared to MOR-EVE. Findings support the benefits of nutrient timing on training-induced muscular adaptations. The study was limited by the addition of creatine monohydrate to the supplement, which may have facilitated increased uptake following training. Moreover, the fact that the supplement was taken both pre- and post-workout confounds whether an anabolic window mediated results.

Willoughby et al. [71] also found that nutrient timing resulted in positive muscular adaptations. Nineteen untrained male subjects were randomly assigned to either receive $20 \mathrm{~g}$ of protein or 20 grams dextrose administered 1 hour before and after resistance exercise. Training consisted of 3 sets of 6-8 repetitions at $85 \%-$ $90 \%$ intensity. Training was performed 4 times a week over the course of 10 weeks. At the end of the study period, total body mass, fat-free mass, and thigh mass was significantly greater in the protein-supplemented group compared to the group that received dextrose. Given that the group receiving the protein supplement consumed an additional 40 grams of protein on training days, it is difficult to discern whether results were due to the increased protein intake or the timing of the supplement.

In a comprehensive study of well-trained subjects, Hoffman et al. [74] randomly assigned 33 well-trained males to receive a protein supplement either in the morning and evening $(n=13)$ or immediately before and immediately after resistance exercise $(n=13)$. Seven participants served as unsupplemented controls. Workouts consisted of 3-4 sets of 6-10 repetitions of multiple exercises for the entire body. Training was carried out on 4 day-a-week split routine with intensity progressively increased over the course of the study period. After 10 weeks, no significant differences were noted between groups with respect to body mass and lean body mass. The study was limited by its use of DXA to assess body composition, which lacks the sensitivity to detect small changes in muscle mass compared to other imaging modalities such as MRI and CT [76].

Hulmi et al. [72] randomized 31 young untrained male subjects into 1 of 3 groups: protein supplement $(n=11)$, non-caloric placebo $(n=10)$ or control $(n=10)$. Highintensity resistance training was carried out over 21 weeks. Supplementation was provided before and after exercise. At the end of the study period, muscle CSA was significantly greater in the protein-supplemented group compared to placebo or control. A strength of the study was its long-term training period, providing support for the beneficial effects of nutrient timing on chronic hypertrophic gains. Again, however, it is unclear whether enhanced results associated with protein supplementation were due to timing or increased protein consumption.

Most recently, Erskine et al. [75] failed to show a hypertrophic benefit from post-workout nutrient timing. Subjects were 33 untrained young males, pair-matched for habitual protein intake and strength response to a 3week pre-study resistance training program. After a 6week washout period where no training was performed, subjects were then randomly assigned to receive either a protein supplement or a placebo immediately before and after resistance exercise. Training consisted of 6- 8 sets of elbow flexion carried out 3 days a week for 12 weeks. 
No significant differences were found in muscle volume or anatomical cross-sectional area between groups.

\section{Discussion}

Despite claims that immediate post-exercise nutritional intake is essential to maximize hypertrophic gains, evidence-based support for such an "anabolic window of opportunity" is far from definitive. The hypothesis is based largely on the pre-supposition that training is carried out in a fasted state. During fasted exercise, a concomitant increase in muscle protein breakdown causes the preexercise net negative amino acid balance to persist in the post-exercise period despite training-induced increases in muscle protein synthesis [36]. Thus, in the case of resistance training after an overnight fast, it would make sense to provide immediate nutritional intervention--ideally in the form of a combination of protein and carbohydrate-for the purposes of promoting muscle protein synthesis and reducing proteolysis, thereby switching a net catabolic state into an anabolic one. Over a chronic period, this tactic could conceivably lead cumulatively to an increased rate of gains in muscle mass.

This inevitably begs the question of how pre-exercise nutrition might influence the urgency or effectiveness of post-exercise nutrition, since not everyone engages in fasted training. In practice, it is common for those with the primary goal of increasing muscular size and/or strength to make a concerted effort to consume a preexercise meal within 1-2 hours prior to the bout in attempt to maximize training performance. Depending on its size and composition, this meal can conceivably function as both a pre- and an immediate post-exercise meal, since the time course of its digestion/absorption can persist well into the recovery period. Tipton et al. [63] observed that a relatively small dose of EAA $(6 \mathrm{~g})$ taken immediately pre-exercise was able to elevate blood and muscle amino acid levels by roughly $130 \%$, and these levels remained elevated for 2 hours after the exercise bout. Although this finding was subsequently challenged by Fujita et al. [64], other research by Tipton et al. [65] showed that the ingestion of $20 \mathrm{~g}$ whey taken immediately pre-exercise elevated muscular uptake of amino acids to 4.4 times pre-exercise resting levels during exercise, and did not return to baseline levels until 3 hours post-exercise. These data indicate that even minimal-tomoderate pre-exercise EAA or high-quality protein taken immediately before resistance training is capable of sustaining amino acid delivery into the post-exercise period. Given this scenario, immediate post-exercise protein dosing for the aim of mitigating catabolism seems redundant. The next scheduled protein-rich meal (whether it occurs immediately or 1-2 hours post-exercise) is likely sufficient for maximizing recovery and anabolism.
On the other hand, there are others who might train before lunch or after work, where the previous meal was finished 4-6 hours prior to commencing exercise. This lag in nutrient consumption can be considered significant enough to warrant post-exercise intervention if muscle retention or growth is the primary goal. Layman [77] estimated that the anabolic effect of a meal lasts 5-6 hours based on the rate of postprandial amino acid metabolism. However, infusion-based studies in rats [78,79] and humans $[80,81]$ indicate that the postprandial rise in MPS from ingesting amino acids or a protein-rich meal is more transient, returning to baseline within 3 hours despite sustained elevations in amino acid availability. It thus has been hypothesized that a "muscle full" status can be reached where MPS becomes refractory, and circulating amino acids are shunted toward oxidation or fates other than MPS. In light of these findings, when training is initiated more than $\sim 3-4$ hours after the preceding meal, the classical recommendation to consume protein (at least $25 \mathrm{~g}$ ) as soon as possible seems warranted in order to reverse the catabolic state, which in turn could expedite muscular recovery and growth. However, as illustrated previously, minor preexercise nutritional interventions can be undertaken if a significant delay in the post-exercise meal is anticipated.

An interesting area of speculation is the generalizability of these recommendations across training statuses and age groups. Burd et al. [82] reported that an acute bout of resistance training in untrained subjects stimulates both mitochondrial and myofibrillar protein synthesis, whereas in trained subjects, protein synthesis becomes more preferential toward the myofibrillar component. This suggests a less global response in advanced trainees that potentially warrants closer attention to protein timing and type (e.g., high-leucine sources such as dairy proteins) in order to optimize rates of muscular adaptation. In addition to training status, age can influence training adaptations. Elderly subjects exhibit what has been termed "anabolic resistance," characterized by a lower receptivity to amino acids and resistance training [83]. The mechanisms underlying this phenomenon are not clear, but there is evidence that in younger adults, the acute anabolic response to protein feeding appears to plateau at a lower dose than in elderly subjects. Illustrating this point, Moore et al. [84] found that $20 \mathrm{~g}$ whole egg protein maximally stimulated post-exercise MPS, while $40 \mathrm{~g}$ increased leucine oxidation without any further increase in MPS in young men. In contrast, Yang et al. [85] found that elderly subjects displayed greater increases in MPS when consuming a postexercise dose of $40 \mathrm{~g}$ whey protein compared to $20 \mathrm{~g}$. These findings suggest that older subjects require higher individual protein doses for the purpose of optimizing the anabolic response to training. Further research is needed to better assess post-workout nutrient timing response 
across various populations, particularly with respect to trained/untrained and young/elderly subjects.

The body of research in this area has several limitations. First, while there is an abundance of acute data, controlled, long-term trials that systematically compare the effects of various post-exercise timing schemes are lacking. The majority of chronic studies have examined pre- and post-exercise supplementation simultaneously, as opposed to comparing the two treatments against each other. This prevents the possibility of isolating the effects of either treatment. That is, we cannot know whether pre- or post-exercise supplementation was the critical contributor to the outcomes (or lack thereof). Another important limitation is that the majority of chronic studies neglect to match total protein intake between the conditions compared. As such, it's not possible to ascertain whether positive outcomes were influenced by timing relative to the training bout, or simply by a greater protein intake overall. Further, dosing strategies employed in the preponderance of chronic nutrient timing studies have been overly conservative, providing only 10-20 g protein near the exercise bout. More research is needed using protein doses known to maximize acute anabolic response, which has been shown to be approximately 20-40 g, depending on age $[84,85]$. There is also a lack of chronic studies examining the co-ingestion of protein and carbohydrate near training. Thus far, chronic studies have yielded equivocal results. On the whole, they have not corroborated the consistency of positive outcomes seen in acute studies examining post-exercise nutrition.

Another limitation is that the majority of studies on the topic have been carried out in untrained individuals. Muscular adaptations in those without resistance training experience tend to be robust, and do not necessarily reflect gains experienced in trained subjects. It therefore remains to be determined whether training status influences the hypertrophic response to post-exercise nutritional supplementation.

A final limitation of the available research is that current methods used to assess muscle hypertrophy are widely disparate, and the accuracy of the measures obtained are inexact [68]. As such, it is questionable whether these tools are sensitive enough to detect small differences in muscular hypertrophy. Although minor variances in muscle mass would be of little relevance to the general population, they could be very meaningful for elite athletes and bodybuilders. Thus, despite conflicting evidence, the potential benefits of post-exercise supplementation cannot be readily dismissed for those seeking to optimize a hypertrophic response. By the same token, widely varying feeding patterns among individuals challenge the common assumption that the post-exercise "anabolic window of opportunity" is universally narrow and urgent.

\section{Practical applications}

Distilling the data into firm, specific recommendations is difficult due to the inconsistency of findings and scarcity of systematic investigations seeking to optimize preand/or post-exercise protein dosage and timing. Practical nutrient timing applications for the goal of muscle hypertrophy inevitably must be tempered with field observations and experience in order to bridge gaps in the scientific literature. With that said, high-quality protein dosed at $0.4-0.5 \mathrm{~g} / \mathrm{kg}$ of LBM at both pre- and post-exercise is a simple, relatively fail-safe general guideline that reflects the current evidence showing a maximal acute anabolic effect of 20-40 g [53,84,85]. For example, someone with $70 \mathrm{~kg}$ of LBM would consume roughly 28-35 g protein in both the pre- and post exercise meal. Exceeding this would be have minimal detriment if any, whereas significantly under-shooting or neglecting it altogether would not maximize the anabolic response.

Due to the transient anabolic impact of a protein-rich meal and its potential synergy with the trained state, pre- and post-exercise meals should not be separated by more than approximately 3-4 hours, given a typical resistance training bout lasting 45-90 minutes. If protein is delivered within particularly large mixed-meals (which are inherently more anticatabolic), a case can be made for lengthening the interval to 5-6 hours. This strategy covers the hypothetical timing benefits while allowing significant flexibility in the length of the feeding windows before and after training. Specific timing within this general framework would vary depending on individual preference and tolerance, as well as exercise duration. One of many possible examples involving a 60minute resistance training bout could have up to 90minute feeding windows on both sides of the bout, given central placement between the meals. In contrast, bouts exceeding typical duration would default to shorter feeding windows if the 3-4 hour pre- to post-exercise meal interval is maintained. Shifting the training session closer to the pre- or post-exercise meal should be dictated by personal preference, tolerance, and lifestyle/ scheduling constraints.

Even more so than with protein, carbohydrate dosage and timing relative to resistance training is a gray area lacking cohesive data to form concrete recommendations. It is tempting to recommend pre- and postexercise carbohydrate doses that at least match or exceed the amounts of protein consumed in these meals. However, carbohydrate availability during and after exercise is of greater concern for endurance as opposed to strength or hypertrophy goals. Furthermore, the importance of co-ingesting post-exercise protein and carbohydrate has recently been challenged by studies examining the early recovery period, particularly when sufficient 
protein is provided. Koopman et al [52] found that after full-body resistance training, adding carbohydrate $(0.15$, or $0.6 \mathrm{~g} / \mathrm{kg} / \mathrm{hr})$ to amply dosed casein hydrolysate $(0.3 \mathrm{~g} /$ $\mathrm{kg} / \mathrm{hr}$ ) did not increase whole body protein balance during a 6-hour post-exercise recovery period compared to the protein-only treatment. Subsequently, Staples et al [53] reported that after lower-body resistance exercise (leg extensions), the increase in post-exercise muscle protein balance from ingesting $25 \mathrm{~g}$ whey isolate was not improved by an additional $50 \mathrm{~g}$ maltodextrin during a 3hour recovery period. For the goal of maximizing rates of muscle gain, these findings support the broader objective of meeting total daily carbohydrate need instead of specifically timing its constituent doses. Collectively, these data indicate an increased potential for dietary flexibility while maintaining the pursuit of optimal timing.

\section{Competing interests}

The authors declare that they have no competing interests.

\section{Authors' contribution}

AAA and BJS each contributed equally to the formulation and writing of the manuscript. Both authors read and approved the final manuscript.

\section{Author details}

${ }^{1}$ California State University, Northridge, CA, USA. ${ }^{2}$ Department of Health Science, Lehman College, Bronx, NY, USA.

Received: 20 December 2012 Accepted: 25 January 2013 Published: 29 January 2013

\section{References}

1. Kerksick C, Harvey T, Stout J, Campbell B, Wilborn C, Kreider R, Kalman D, Ziegenfuss T, Lopez H, Landis J, Ivy JL, Antonio J: International Society of Sports Nutrition position stand: nutrient timing. I Int Soc Sports Nutr. 2008, 5:17.

2. Ivy J, Portman R: Nutrient Timing: The Future of Sports Nutrition. North Bergen, NJ: Basic Health Publications; 2004.

3. Candow DG, Chilibeck PD: Timing of creatine or protein supplementation and resistance training in the elderly. Appl Physiol Nutr Metab 2008, 33 (1):184-90.

4. Hulmi JJ, Lockwood CM, Stout JR: Effect of protein/essential amino acids and resistance training on skeletal muscle hypertrophy: A case for whey protein. Nutr Metab (Lond). 2010, 7:51.

5. Kukuljan S, Nowson CA, Sanders K, Daly RM: Effects of resistance exercise and fortified milk on skeletal muscle mass, muscle size, and functional performance in middle-aged and older men: an 18-mo randomized controlled trial. J Appl Physiol 2009, 107(6):1864-73.

6. Lambert CP, Flynn MG: Fatigue during high-intensity intermittent exercise: application to bodybuilding. Sports Med. 2002, 32(8):511-22.

7. MacDougall JD, Ray S, Sale DG, McCartney N, Lee P, Garner S: Muscle substrate utilization and lactate production. Can J Appl Physiol 1999, 24(3):209-15.

8. Robergs RA, Pearson DR, Costill DL, Fink WJ, Pascoe DD, Benedict MA, Lambert CP, Zachweija JJ: Muscle glycogenolysis during differing intensities of weight-resistance exercise. J Appl Physiol 1991, 70(4):1700-6.

9. Goodman CA, Mayhew DL, Hornberger TA: Recent progress toward understanding the molecular mechanisms that regulate skeletal muscle mass. Cell Signal 2011, 23(12):1896-906.

10. Bodine SC, Stitt TN, Gonzalez M, Kline WO, Stover GL, Bauerlein R, Zlotchenko E, Scrimgeour A, Lawrence JC, Glass DJ, Yancopoulos GD: Akt/ mTOR pathway is a crucial regulator of skeletal muscle hypertrophy and can prevent muscle atrophy in vivo. Nat Cell Biol. 2001, 3(11):1014-9.

11. Jacinto $\mathrm{E}, \mathrm{Hall} \mathrm{MN}$ : Tor signalling in bugs, brain and brawn. Nat Rev Mol Cell Biol 2003, 4(2):117-26.
12. Izumiya Y, Hopkins T, Morris C, Sato K, Zeng L, Viereck J, Hamilton JA, Ouchi $\mathrm{N}$, LeBrasseur NK, Walsh K: Fast/Glycolytic muscle fiber growth reduces fat mass and improves metabolic parameters in obese mice. Cell Metab. 2008, 7(2):159-72.

13. McBride A, Ghilagaber S, Nikolaev A, Hardie DG: The glycogen-binding domain on the AMPK beta subunit allows the kinase to act as a glycogen sensor. Cell Metab. 2009, 9(1):23-34.

14. Wojtaszewski JF, MacDonald C, Nielsen JN, Hellsten Y, Hardie DG, Kemp BE, Kiens B, Richter EA: Regulation of 5'AMP-activated protein kinase activity and substrate utilization in exercising human skeletal muscle. Am J Physiol Endocrinol Metab 2003, 284(4):E813-22.

15. Creer A, Gallagher P, Slivka D, Jemiolo B, Fink W, Trappe S: Influence of muscle glycogen availability on ERK1/2 and Akt signaling after resistance exercise in human skeletal muscle. J Appl Physiol 2005, 99(3):950-6.

16. Churchley EG, Coffey VG, Pedersen DJ, Shield A, Carey KA, Cameron-Smith $D$, Hawley JA: Influence of preexercise muscle glycogen content on transcriptional activity of metabolic and myogenic genes in well-trained humans. J Appl Physiol 2007, 102(4):1604-11.

17. Dennis PB, Jaeschke A, Saitoh M, Fowler B, Kozma SC, Thomas G: Mammalian TOR: a homeostatic ATP sensor. Science 2001, 294(5544):1102-5.

18. Camera DM, West DW, Burd NA, Phillips SM, Garnham AP, Hawley JA, Coffey VG: Low muscle glycogen concentration does not suppress the anabolic response to resistance exercise. J Appl Physiol 2012, 113(2):206-14.

19. Lemon PW, Mullin JP: Effect of initial muscle glycogen levels on protein catabolism during exercise. J Appl Physiol 1980, 48(4):624-9.

20. Blomstrand E, Saltin B, Blomstrand E, Saltin B: Effect of muscle glycogen on glucose, lactate and amino acid metabolism during exercise and recovery in human subjects. J Physiol 1999, 514(1):293-302.

21. Ivy JL: Glycogen resynthesis after exercise: effect of carbohydrate intake. Int J Sports Med. 1998, 19(Suppl 2):S142-5.

22. Richter EA, Derave W, Wojtaszewski JF: Glucose, exercise and insulin: emerging concepts. J Physiol 2001, 535(Pt 2):313-22.

23. Derave W, Lund S, Holman GD, Wojtaszewski J, Pedersen O, Richter EA Contraction-stimulated muscle glucose transport and GLUT-4 surface content are dependent on glycogen content. Am J Physiol 1999, 277 (6 Pt 1):E1103-10.

24. Kawanaka K, Nolte LA, Han DH, Hansen PA, Holloszy JO: Mechanisms underlying impaired GLUT-4 translocation in glycogensupercompensated muscles of exercised rats. Am J Physiol Endocrinol Metab 2000, 279(6):E1311-8.

25. O'Gorman DJ, Del Aguila LF, Williamson DL, Krishnan RK, Kirwan JP: Insulin and exercise differentially regulate $\mathrm{Pl} 3$-kinase and glycogen synthase in human skeletal muscle. J Appl Physiol 2000, 89(4):1412-9.

26. Berardi JM, Price TB, Noreen EE, Lemon PW: Postexercise muscle glycogen recovery enhanced with a carbohydrate-protein supplement. Med Sci Sports Exerc. 2006, 38(6):1106-13.

27. Ivy JL, Goforth HW Jr, Damon BM, McCauley TR, Parsons EC, Price TB: Early postexercise muscle glycogen recovery is enhanced with a carbohydrate-protein supplement. J Appl Physiol 2002, 93(4):1337-44.

28. Zawadzki KM, Yaspelkis BB 3rd, IVy JL: Carbohydrate-protein complex increases the rate of muscle glycogen storage after exercise. J Appl Physiol 1992, 72(5):1854-9.

29. Tarnopolsky MA, Bosman M, Macdonald JR, Vandeputte D, Martin J, Roy BD: Postexercise protein-carbohydrate and carbohydrate supplements increase muscle glycogen in men and women. J Appl Physiol 1997, 83(6):1877-83.

30. Jentjens RL, van Loon $L$, Mann $C H$, Wagenmakers AJ, Jeukendrup AE: Addition of protein and amino acids to carbohydrates does not enhance postexercise muscle glycogen synthesis. J Appl Physiol 2001, 91(2):839-46.

31. Jentjens $R$, Jeukendrup $A$ : Determinants of post-exercise glycogen synthesis during short-term recovery. Sports Med. 2003, 33(2):117-44.

32. Roy BD, Tarnopolsky MA: Influence of differing macronutrient intakes on muscle glycogen resynthesis after resistance exercise. J Appl Physiol 1998, 84(3):890-6.

33. Parkin JA, Carey MF, Martin IK, Stojanovska L, Febbraio MA: Muscle glycogen storage following prolonged exercise: effect of timing of ingestion of high glycemic index food. Med Sci Sports Exerc. 1997, 29(2):220-4

34. Fox AK, Kaufman AE, Horowitz JF: Adding fat calories to meals after exercise does not alter glucose tolerance. J Appl Physiol 2004, 97(1):11-6. 
35. Biolo G, Tipton KD, Klein S, Wolfe RR: An abundant supply of amino acids enhances the metabolic effect of exercise on muscle protein. Am J Physiol 1997, 273(1 Pt 1):E122-9.

36. Kumar $V$, Atherton $P$, Smith $K$, Rennie MJ: Human muscle protein synthesis and breakdown during and after exercise. J Appl Physiol 2009, 106(6):2026-39.

37. Pitkanen HT, Nykanen T, Knuutinen J, Lahti K, Keinanen O, Alen M, Komi PV, Mero AA: Free amino acid pool and muscle protein balance after resistance exercise. Med Sci Sports Exerc. 2003, 35(5):784-92.

38. Biolo G, Williams BD, Fleming RY, Wolfe RR: Insulin action on muscle protein kinetics and amino acid transport during recovery after resistance exercise. Diabetes 1999, 48(5):949-57.

39. Fluckey JD, Vary TC, Jefferson LS, Farrell PA: Augmented insulin action on rates of protein synthesis after resistance exercise in rats. Am J Physio 1996, 270(2 Pt 1):E313-9

40. Denne SC, Liechty EA, Liu YM, Brechtel G, Baron AD: Proteolysis in skeletal muscle and whole body in response to euglycemic hyperinsulinemia in normal adults. Am J Physiol 1991, 261(6 Pt 1):E809-14.

41. Gelfand RA, Barrett EJ: Effect of physiologic hyperinsulinemia on skeletal muscle protein synthesis and breakdown in man. J Clin Invest 1987, 80(1):1-6.

42. Heslin MJ, Newman E, Wolf RF, Pisters PW, Brennan MF: Effect of hyperinsulinemia on whole body and skeletal muscle leucine carbon kinetics in humans. Am J Physio/ 1992, 262(6 Pt 1):E911-8.

43. Kettelhut IC, Wing SS, Goldberg AL: Endocrine regulation of protein breakdown in skeletal muscle. Diabetes Metab Rev. 1988, 4(8):751-72.

44. Kim DH, Kim JY, Yu BP, Chung HY: The activation of NF-kappaB through Akt-induced FOXO1 phosphorylation during aging and its modulation by calorie restriction. Biogerontology 2008, 9(1):33-47.

45. Greenhaff PL, Karagounis LG, Peirce N, Simpson EJ, Hazell M, Layfield R, Wackerhage $\mathrm{H}$, Smith K, Atherton P, Selby A, Rennie MJ: Disassociation between the effects of amino acids and insulin on signaling, ubiquitin ligases, and protein turnover in human muscle. Am J Physiol Endocrinol Metab 2008, 295(3):E595-604

46. Rennie MJ, Bohe J, Smith K, Wackerhage H, Greenhaff P: Branched-chain amino acids as fuels and anabolic signals in human muscle. J Nutr 2006 136(1 Suppl):264S-8S.

47. Capaldo B, Gastaldelli A, Antoniello S, Auletta M, Pardo F, Ciociaro D, Guida R, Ferrannini E, Sacca L: Splanchnic and leg substrate exchange after ingestion of a natural mixed meal in humans. Diabetes 1999, 48(5):958-66.

48. Power $\mathrm{O}$, Hallihan A, Jakeman P: Human insulinotropic response to oral ingestion of native and hydrolysed whey protein. Amino Acids. 2009, 37(2):333-9.

49. Glynn EL, Fry CS, Drummond MJ, Dreyer HC, Dhanani S, Volpi E, Rasmussen BB: Muscle protein breakdown has a minor role in the protein anabolic response to essential amino acid and carbohydrate intake following resistance exercise. Am J Physiol Regul Integr Comp Physiol 2010, 299(2): R533-40.

50. Tipton KD, Ferrando AA, Phillips SM, Doyle D Jr, Wolfe RR: Postexercise net protein synthesis in human muscle from orally administered amino acids. Am J Physiol 1999, 276(4 Pt 1):E628-34.

51. Miller SL, Tipton KD, Chinkes DL, Wolf SE, Wolfe RR: Independent and combined effects of amino acids and glucose after resistance exercise. Med Sci Sports Exerc. 2003, 35(3):449-55.

52. Koopman R, Beelen M, Stellingwerff T, Pennings B, Saris WH, Kies AK Kuipers $\mathrm{H}$, van Loon $\mathrm{LJ}$ : Coingestion of carbohydrate with protein does not further augment postexercise muscle protein synthesis. Am J Physiol Endocrinol Metab 2007, 293(3):E833-42.

53. Staples AW, Burd NA, West DW, Currie KD, Atherton PJ, Moore DR, Rennie MJ, Macdonald MJ, Baker SK, Phillips SM: Carbohydrate does not augment exercise-induced protein accretion versus protein alone. Med Sci Sports Exerc. 2011, 43(7):1154-61.

54. Borsheim E, Cree MG, Tipton KD, Elliott TA, Aarsland A, Wolfe RR: Effect of carbohydrate intake on net muscle protein synthesis during recovery from resistance exercise. J App/ Physio/ 2004, 96(2):674-8.

55. Koopman R, Wagenmakers AJ, Manders RJ, Zorenc AH, Senden JM, Gorselink M, Keizer HA, van Loon LJ: Combined ingestion of protein and free leucine with carbohydrate increases postexercise muscle protein synthesis in vivo in male subjects. Am J Physiol Endocrinol Metab 2005, 288(4):E645-53.

56. Rasmussen BB, Tipton KD, Miller SL, Wolf SE, Wolfe RR: An oral essential amino acid-carbohydrate supplement enhances muscle protein anabolism after resistance exercise. J Appl Physio/ 2000, 88(2):386-92.
57. Tang JE, Manolakos JJ, Kujbida GW, Lysecki PJ, Moore DR, Phillips SM: Minimal whey protein with carbohydrate stimulates muscle protein synthesis following resistance exercise in trained young men. Appl Physiol Nutr Metab 2007, 32(6):1132-8

58. Tipton KD, Elliott TA, Cree MG, Wolf SE, Sanford AP, Wolfe RR: Ingestion of casein and whey proteins result in muscle anabolism after resistance exercise. Med Sci Sports Exerc. 2004, 36(12):2073-81.

59. Tipton KD, Elliott TA, Ferrando AA, Aarsland AA, Wolfe RR: Stimulation of muscle anabolism by resistance exercise and ingestion of leucine plus protein. Appl Physiol Nutr Metab 2009, 34(2):151-61.

60. Phillips SM, Van Loon L: Dietary protein for athletes: from requirements to optimum adaptation. J Sports Sci. 2011, 29(Suppl 1):S29-38.

61. Phillips SM: The science of muscle hypertrophy: making dietary protein count. Proc Nutr Soc 2011, 70(1):100-3.

62. Levenhagen DK, Gresham JD, Carlson MG, Maron DJ, Borel MJ, Flakoll PJ: Postexercise nutrient intake timing in humans is critical to recovery of leg glucose and protein homeostasis. Am J Physiol Endocrinol Metab 2001 280(6):E982-93.

63. Tipton KD, Rasmussen BB, Miller SL, Wolf SE, Owens-Stovall SK, Petrini BE, Wolfe RR: Timing of amino acid-carbohydrate ingestion alters anabolic response of muscle to resistance exercise. Am J Physiol Endocrinol Metab 2001, 281(2):E197-206.

64. Fujita S, Dreyer HC, Drummond MJ, Glynn EL, Volpi E, Rasmussen BB: Essential amino acid and carbohydrate ingestion before resistance exercise does not enhance postexercise muscle protein synthesis. J Appl Physiol 2009, 106(5):1730-9.

65. Tipton KD, Elliott TA, Cree MG, Aarsland AA, Sanford AP, Wolfe RR: Stimulation of net muscle protein synthesis by whey protein ingestion before and after exercise. Am J Physiol Endocrinol Metab 2007, 292(1):E71-6.

66. Coffey VG, Shield A, Canny BJ, Carey KA, Cameron-Smith D, Hawley JA: Interaction of contractile activity and training history on mRNA abundance in skeletal muscle from trained athletes. Am J Physiol Endocrinol Metab 2006, 290(5):E849-55.

67. Timmons JA: Variability in training-induced skeletal muscle adaptation. J Appl Physiol 2011, 110(3):846-53.

68. Adams G, Bamman MM: Characterization and regulation of mechanical loading-induced compensatory muscle hypertrophy. Comprehensive Physiology 2012, 2829:2970.

69. Esmarck B, Andersen JL, Olsen S, Richter EA, Mizuno M, Kjaer M: Timing of postexercise protein intake is important for muscle hypertrophy with resistance training in elderly humans. J Physiol 2001, 535(Pt 1):301-11.

70. Cribb PJ, Hayes A: Effects of supplement timing and resistance exercise on skeletal muscle hypertrophy. Med Sci Sports Exerc. 2006, 38(11):1918-25.

71. Willoughby DS, Stout JR, Wilborn CD: Effects of resistance training and protein plus amino acid supplementation on muscle anabolism, mass, and strength. Amino Acids. 2007, 32(4):467-77.

72. Hulmi JJ, Kovanen V, Selanne H, Kraemer WJ, Hakkinen K, Mero AA: Acute and long-term effects of resistance exercise with or without protein ingestion on muscle hypertrophy and gene expression. Amino Acids. 2009, 37(2):297-308.

73. Verdijk LB, Jonkers RA, Gleeson BG, Beelen M, Meijer K, Savelberg HH, Wodzig WK, Dendale P, van Loon LJ: Protein supplementation before and after exercise does not further augment skeletal muscle hypertrophy after resistance training in elderly men. Am J Clin Nutr 2009, 89(2):608-16.

74. Hoffman JR, Ratamess NA, Tranchina CP, Rashti SL, Kang J, Faigenbaum AD: Effect of protein-supplement timing on strength, power, and bodycomposition changes in resistance-trained men. Int J Sport Nutr Exerc Metab. 2009, 19(2):172-85.

75. Erskine RM, Fletcher G, Hanson B, Folland JP: Whey protein does not enhance the adaptations to elbow flexor resistance training. Med Sci Sports Exerc. 2012, 44(9):1791-800.

76. Levine JA, Abboud L, Barry M, Reed JE, Sheedy PF, Jensen MD: Measuring leg muscle and fat mass in humans: comparison of $\mathrm{CT}$ and dual-energy X-ray absorptiometry. J App/ Physiol 2000, 88(2):452-6.

77. Layman DK: Protein quantity and quality at levels above the RDA improves adult weight loss. J Am Coll Nutr 2004, 23(6 Suppl):631S-6S

78. Norton LE, Layman DK, Bunpo P, Anthony TG, Brana DV, Garlick PJ: The leucine content of a complete meal directs peak activation but not duration of skeletal muscle protein synthesis and mammalian target of rapamycin signaling in rats. J Nutr 2009, 139(6):1103-9. 
79. Wilson GJ, Layman DK, Moulton CJ, Norton LE, Anthony TG, Proud CG, Rupassara SI, Garlick PJ: Leucine or carbohydrate supplementation reduces AMPK and eEF2 phosphorylation and extends postprandial muscle protein synthesis in rats. Am J Physiol Endocrinol Metab 2011, 301(6):E1236-42.

80. Atherton PJ, Etheridge T, Watt PW, Wilkinson D, Selby A, Rankin D, Smith K, Rennie MJ: Muscle full effect after oral protein: time-dependent concordance and discordance between human muscle protein synthesis and mTORC1 signaling. Am J Clin Nutr 2010, 92(5):1080-8.

81. Bohe J, Low JF, Wolfe RR, Rennie MJ: Latency and duration of stimulation of human muscle protein synthesis during continuous infusion of amino acids. J Physiol 2001, 532(Pt 2):575-9.

82. Burd NA, Tang JE, Moore DR, Phillips SM: Exercise training and protein metabolism: influences of contraction, protein intake, and sex-based differences. J Appl Physiol 2009, 106(5):1692-701.

83. Breen L, Phillips SM: Interactions between exercise and nutrition to prevent muscle waste during aging. Br J Clin Pharmacol 2012. doi:10.1111/ j.1365-2125.2012.04456.x [Epub ahead of print].

84. Moore DR, Robinson MJ, Fry JL, Tang JE, Glover El, Wilkinson SB, Prior T, Tarnopolsky MA, Phillips SM: Ingested protein dose response of muscle and albumin protein synthesis after resistance exercise in young men. Am J Clin Nutr 2009, 89(1):161-8.

85. Yang Y, Breen L, Burd NA, Hector AJ, Churchward-Venne TA, Josse AR, Tarnopolsky MA, Phillips SM: Resistance exercise enhances myofibrillar protein synthesis with graded intakes of whey protein in older men. Br J Nutr 2012, 108(10):1780-8.

doi:10.1186/1550-2783-10-5

Cite this article as: Aragon and Schoenfeld: Nutrient timing revisited: is there a post-exercise anabolic window?. Journal of the International

Society of Sports Nutrition 2013 10:5.

\section{Submit your next manuscript to BioMed Central and take full advantage of:}

- Convenient online submission

- Thorough peer review

- No space constraints or color figure charges

- Immediate publication on acceptance

- Inclusion in PubMed, CAS, Scopus and Google Scholar

- Research which is freely available for redistribution 